\section{Endothelial cell apoptosis in brown adipose tissue of rats induced by hyperinsulinaemia: the possible role of TNF- $\alpha$}

\author{
M. Markelic, ${ }^{1}$ K. Velickovic, ${ }^{1}$ I. Golic, ${ }^{1}$ \\ V. Otasevic, ${ }^{2}$ A. Stancic, ${ }^{2}$ A. Jankovic, ${ }^{2}$ \\ M. Vucetic, ${ }^{2}$ B. Buzadzic, ${ }^{2}$ B. Korac, ${ }^{2}$
} A. Korac'

'Faculty of Biology, Centre for Electron Microscopy, University of Belgrade; IInstitute for Biological Research Sinisa Stankovic, University of Belgrade, Serbia

\begin{abstract}
The aim of the present study was to investigate whether hyperinsulinaemia, which frequently precedes insulin resistance syndrome (obesity, diabetes), induces apoptosis of endothelial cells (ECs) in brown adipose tissue (BAT) and causes BAT atrophy and also, to investigate the possible mechanisms underlying ECs death. In order to induce hyperinsulinaemia, adult male rats of Wistar strain were treated with high dose of insulin (4 U/kg, intraperitonely) for one or three days. Examinations at ultrastructural level showed apoptotic changes of ECs, allowing us to point out that changes mainly but not exclusively, occur in nuclei. Besides different stages of condensation and alterations of the chromatin, nuclear fragmentation was also observed. Higher number of ECs apoptotic nuclei in the BAT of hyperinsulinaemic rats was also confirmed by propidium iodide staining. Immunohistochemical localization of tumor necrosis factor-alpha (TNF- $\alpha$ ) revealed increased expression in ECs of BAT of hyperinsulinaemic animals, indicating its possible role in insulin-induced apoptotic changes. These results suggest that BAT atrophy in hyperinsulinaemia is a result of endothelial and adipocyte apoptosis combined, rather than any of functional components alone.
\end{abstract}

\section{Introduction}

The importance of brown adipose tissue (BAT) in metabolic regulation of energy balance is well established. Namely, BAT has an unique ability of heat production and body temperature maintenance in mammals. ${ }^{1}$ Until now the main focus of brown fat investigation was on brown adipocytes although it is well known that all of three major components of BAT are important for its thermogenic func- tion: i) brown adipocyte's mitochondria and lipid droplets; ii) sympathetic innervation; and iii) capillary network..$^{2-6}$ An important characteristic of BAT and white adipose tissue (WAT) is their enormous plasticity, i.e., their capability of volume changes and, to a lesser extent, cell number variations. It has also been recognized that an extensive capillary network surrounds each adipocyte. ${ }^{7}$ This is especially true for brown adipocytes which are considered to be highly vascularized and that almost onethird of brown adipocyte membrane is in direct contact with capillaries. ${ }^{7,8}$ There is a close functional relationship between fat tissue and its vasculature, and angiogenesis is required for both the development and growth of adipose tissue. ${ }^{9-11}$ Therefore, BAT mass is considered to depend on both the number of brown adipocytes and the capillary density. Also, BAT atrophy is involved in development of several metabolic-related diseases (obesity, diabetes). Unlike well documented contribution of brown adipocyte apoptosis to the BAT atrophy, the possible role of endothelial cells (ECs) in that process is still obscure.

Apoptosis is a mode of programmed cell death in which intrinsic cellular mechanisms participate in the removal of cells. The endothelial position between tissues and circulating blood assures its simultaneous and constant exposure to a wide variety of stimuli, many of which have the potential to induce or prevent apoptosis of its cells. ${ }^{12}$ The receptors and exact signal transduction pathways for endothelial pro- and anti-apoptotic stimuli are largely unknown, but the available data seem to support one important conclusion: the local balance of pro- and anti-apoptotic stimuli decides the survival of each individual EC. The modulation of endothelial apoptosis may play a role in atherosclerosis, obesity, angiogenesis, vascular remodelling and other physiological and pathophysiological states and processes. Also, it was found that anti-angiogenic agents can prevent the tissue growth. ${ }^{13}$

BAT is an important target for insulin action and the understanding of its role appears to be of special importance considering the potential influence of in vivo hyperinsulinaemia in the development of obesity. Namely, hyperinsulinaemia and insulin resistance are normal consequences of overfeeding which precedes obesity. Although moderate hyperinsulinaemia might be tolerated in the short term, chronic hyperinsulinaemia exacerbates insulin resistance and contributes directly to diabetes. ${ }^{14}$ In addition, Liu et al. demonstrated that insulin per se is a stronger inducer of insulin resistance than hyperglycemia, at least in type 1 diabetes. ${ }^{15}$ Our previous study showed hyperinsulinaemia-induced brown adipocytes apoptosis, ${ }^{16}$ which was also confirmed in the cell culture by other laboratories. ${ }^{17}$ Thus, we were
Correspondence: Dr. Aleksandra Korać, University of Belgrade, Faculty of Biology, Studentski trg 16, 11000 Belgrade, Serbia.

Tel. +381.11.2187266 ext. 101 - Fax: +381.11.2638500.

E-mail: aleksandra.korac@bio.bg.ac.rs

Key words: insulin, TNF- $\alpha$, apoptosis, endothelial cell, brown adipose tissue.

Acknowledgements: this work was supported by Serbian Ministry of Education and Science, Grant $\# 173055$.

Conflict of interest: the authors report no conflicts of interest.

Contributions: all authors contributed equally and approve the final version.

Received for publication: 21 March 2011. Accepted for publication: 21 June 2011.

This work is licensed under a Creative Commons Attribution NonCommercial 3.0 License (CC BYNC 3.0).

(C) Copyright M. Markelic et al., 2011

Licensee PAGEPress, Italy

European Journal of Histochemistry 2011; 55:e34 doi:10.4081/ejh.2011.e34

interested in insulin effects on ECs survival since they are structurally and functionally accompanied to brown adipocytes.

We were also interested in the examination of TNF- $\alpha$ role as a link between adiposity and the development of insulin resistance since this cytokine has a role in limiting fat mass through the induction of insulin resistance and represents a key-link in this process. Namely, majority of type 2 diabetic subjects are obese, and this cytokine is highly expressed in adipose tissues of obese subjects ${ }^{17}$ and also, obese mice lacking either TNF- $\alpha$ or its receptors showed protection against developing insulin resistance. ${ }^{18}$ Because of its ability to inhibit insulin receptor signaling, ${ }^{19-21}$ TNF- $\alpha$ represents a component of obesity-related insulin resistance ${ }^{22}$ and has also been shown to induce brown and white adipocyte apoptosis. ${ }^{23-26}$ Besides, there are some findings suggesting that TNF- $\alpha$ exerts antiangiogenic effect by EC-specific effects ${ }^{27}$ and that its activation may, directly or indirectly, contribute to the pathogenesis and development of microvascular diabetic complications. ${ }^{28}$ Therefore, we studied effects of hyperinsulinaemia on EC apoptosis in BAT of hyperinsulinaemic rats and the possible role of TNF- $\alpha$ in this process.

Apoptotic changes of ECs nuclei were visualized by transmission electron microscopic analysis and by propidium iodide staining, while proinflammatory cytokine TNF- $\alpha$ was detected by immunohistochemical labeling. 


\section{Materials and Methods}

\section{Experimental analysis and design}

Experimental protocol was approved by the Ethical Committee for the Treatment of Experimental Animals of the Faculty of Biology, Belgrade. Animals were cared for in accordance with the principles of the Guide to the Care and Use of Experimental Animals.

Male albino rats of Wistar strain, weighting 220-250 $\mathrm{g}$ at the beginning of the experiment were used. The animals were born and acclimated to $22 \pm 1^{\circ} \mathrm{C}$ and were maintained under $12 \mathrm{~h}$ light/dark cycle. They were given commercial rat food (Subotica, Serbia) and tap water ad libitum during the experiment. The rats were divided in 4 groups and were injected with insulin for 1 day (acute treatment) or for 3 days (chronic treatment) respectively, (4 $\mathrm{U} / \mathrm{kg}$ of body mass, one dose per day, intraperitonely), or in the same way, with saline (1 $\mathrm{mL} / \mathrm{kg}$, vehicle groups). Three hours after the last injection the animals were sacrificed and the interscapular portion of BAT was removed, dissected and processed for electron and light microscopic examinations.

\section{Ultrastructural study}

A half portion of BAT was cut into small pieces, fixed in $2.5 \%$ glutaraldehyde in $0.1 \mathrm{M}$ phosphate buffer ( $\mathrm{pH} 7.2$ ) and postfixed in $1 \%$ osmium tetroxide in the same buffer. The specimens were dehydrated through serial ethanol solutions of increasing concentration and were embedded in Araldite (Fluka, Seelze, Germany). For ultramicroscopic examinations the tissue blocks were trimmed and cut with diamond knives (Diatome AG, Biel, Switzerland) on an UC6 ultramicrotome (Leica Microsystems, Wetzlar, Germany). The thin sections were mounted on copper grids, stained with uranyl acetate/lead citrate and examined with a Philips CM 12 transmission electron microscope (Philips/FEI, Amsterdam, The Netherlands). For comparative histological analysis of BAT, semi-thin sections of Araldite embedded tissue samples were prepared and stained with basic fuchsin and methylene blue.

\section{Propidium iodide staining}

Immediately after removal, the samples of BAT were fixed in a $10 \%$ formaldehyde solution at $4^{\circ} \mathrm{C}$ overnight and processed routinely for embedding in paraffin. For the analysis of chromatin condensation and apoptotic changes of nuclei, $5 \mu \mathrm{m}$ thick paraffin embedded BAT sections were deparaffinized, rehydrated and dyed with propidium iodide for 10 min. After washing in distilled water, in order to preserve fluorescence signal, the sections were mounted in Mowiol solution (Poly sciences, Eppelheim, Germany) and examined with Carl Zeiss LSM 510 confocal laser scanning microscope (Carl Zeiss, Oberkochen, Germany).

\section{Immunohistochemistry}

The BAT samples were fixed and embedded in paraffin as previously described. A series of $5 \mu \mathrm{m}$ thick sections were deparaffinized and rehydrated, than incubated with $3 \% \mathrm{H}_{2} \mathrm{O}_{2}$ in methanol for $10 \mathrm{~min}$ at room temperature to block endogenous peroxidase and followed by three washes in phosphate buffered saline (PBS; pH 7.4) of 5 min each. The sections were incubated with polyclonal goat anti-TNF- $\alpha$ antibody in PBS (dilution 1:200, Santa Cruz Biotechnology Inc., Santa Cruz, CA, USA) overnight at $4^{\circ} \mathrm{C}$, followed by three 5 min PBS washes. Immunodetection was assessed by the Dako LSAB Universal Kit (Dako Scientific, Glostrup, Denmark). After three PBS washes of 5 min each, sections were incubated with
$0.012 \% \mathrm{H}_{2} \mathrm{O}_{2}$ and $0.05 \%$ diaminobenzidine (Sigma-Aldrich Chemie, Munich, Germany) in PBS for 10 min in dark. The sections were rinsed in distilled water, counterstained with hematoxylin, mounted and examined with a Leica DMLB microscope (Leica Microsystems, Wetzlar, Germany).

\section{Results}

Ultrastructural study of capillaries in BAT of hyperinsulinaemic rats revealed apoptotic ECs, showing signs of nuclear and cytoplasmic condensation followed by the lightening and vacuolization of organelles, primarily mitochondria (Figure 1). Macrophages closely positioned to these apoptotic cells were frequently observed (Figure $1 \mathrm{~A}, \mathrm{~B})$. The most frequent changes in the altered ECs were at the nuclear level. Unaltered capillaries of brown fat are constituted of ECs with oval nuclei and more or less abundant cytoplasm containing rare, small
(1)
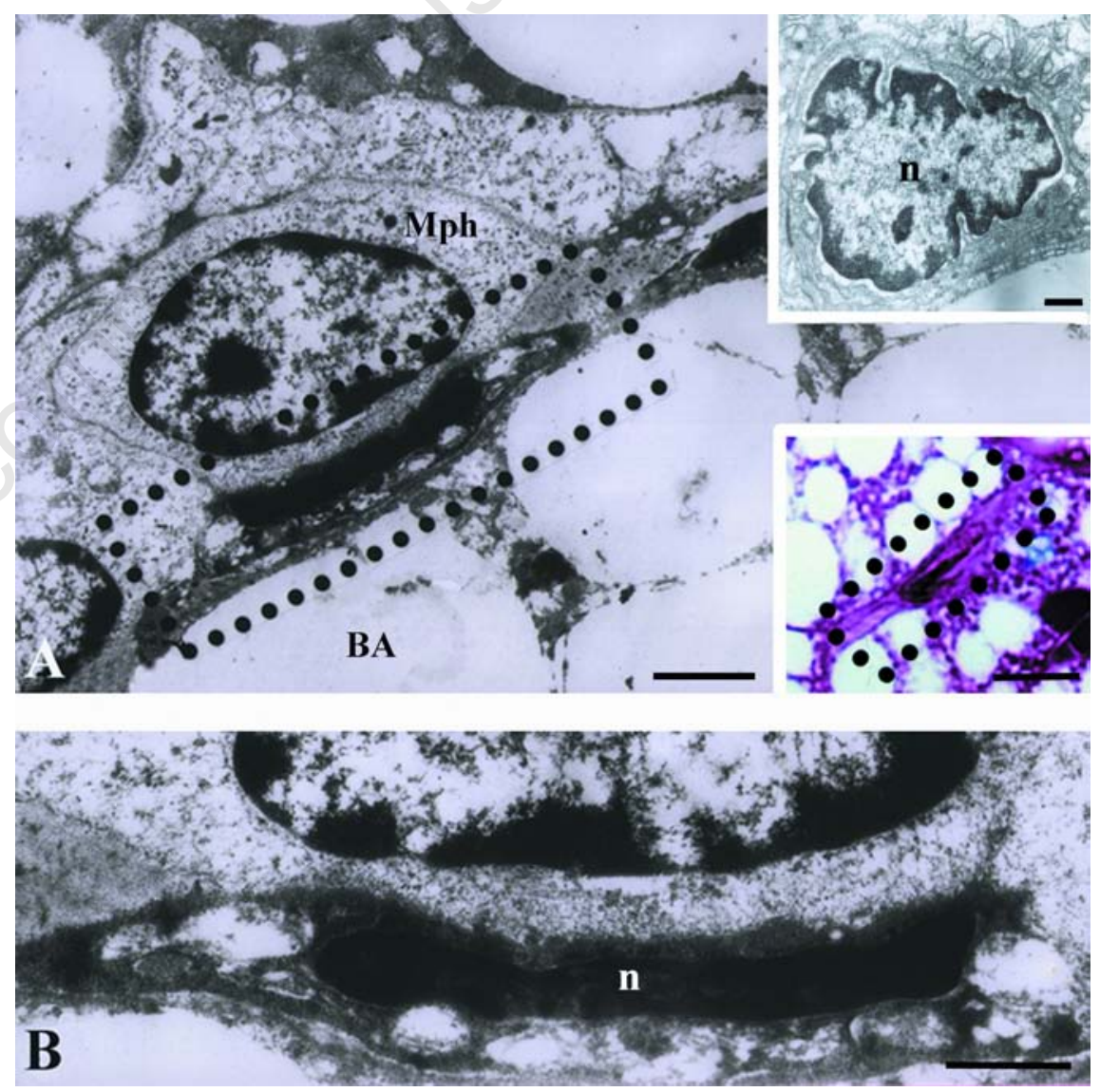

Figure 1. Endothelial cells apoptosis in brown adipose tissue of hyperinsulinaemic rats on electron micrographs (A, B, and upper insertion A) and light micrograph (lower insert in A). Signs of nuclear condensation, cytoplasmic degeneration and organelle vacuolization are visible. $M p h$, macrophage; $B A$, brown adipocyte; $n$, nucleus. Scale bars: A) $1 \mu \mathrm{m} ; A$,

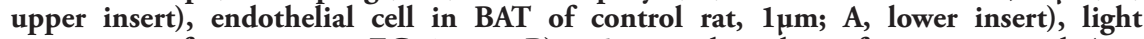
microscopy of an apoptotic EC, $10 \mu \mathrm{m} ; \mathrm{B}), 0.5 \mu \mathrm{m}$, enlarged area from micrograph A. 
mitochondria (Figure 2A). In BAT of hyperinsulinaemic rats heterochromatization and lobulation of ECs nuclei were observed (Figure $2 \mathrm{~B})$, and in some cases, chromatin appeared completely condensed, wooly-like and sparsely distributed in the cell (Figure 3). Besides different stages of chromatin condensation and alterations, cytoplasmic modifications of apoptotic ECs could also be observed. Thus, besides condensation and, in some cases, vacuolization (Figure 3) of endothelial cytoplasm, protrusions of ECs into the capillary lumen were also visible (Figures 3 and 4 ).

Propidium iodide staining (Figure 5 A,B) revealed higher number of ECs nuclei heterochromatization in BAT of insulin treated rats in comparison with BAT of control animals indicating high level of ECs apoptosis after application of high dose of insulin.

TNF- $\alpha$ immunoreactivity was shown in Figure 6. Small blood vessels in BAT revealed stronger TNF- $\alpha$ immunopositivity in ECs of insulin treated animals comparing with control groups, especially in chronically treated animals. In addition, some of the brown adipocytes, especially those in vicinity of TNF$\alpha$ non-positive blood vessels, were immunopositive.

\section{Discussion}

Our study demonstrates that hyperinsulinaemia induces apoptosis of ECs in rat BAT. In both, acute and chronic treatment with high dose of insulin, we revealed increased number of apoptotic ECs in BAT, showing signs of chromatin condensation, nuclear shape alterations, cytoplasmic condensation, and apoptotic bodies' formation. The protrusions of apoptotic ECs we observed (three to five per cell) could be a sign that these damaged cells are detaching from the internal elastic lamina at an early stage of apoptosis and are discarding into the capillary lumen. On the other side, there are many cases of macrophage vicinity to apoptotic ECs which indicate also the phagocytic way of their removal in BAT. Previous study of our team has revealed cytotoxic effects of chronic hyperinsulinaemia in BAT, indicating that apoptosis appears to be the mechanism responsible for the loss of brown adipocytes $^{16}$ which was also shown in the brown adipocyte culture. ${ }^{17}$ Also, high dose of insulin, when applied chronically, leads to decrease in BAT sympathetic innervation (our unpublished data).

From the present study it seems that ECs apoptosis takes a part in BAT remodeling, at least during exposure to high dose of insulin. Combined elimination of brown adipocytes and ECs, could be a mechanism responsible for
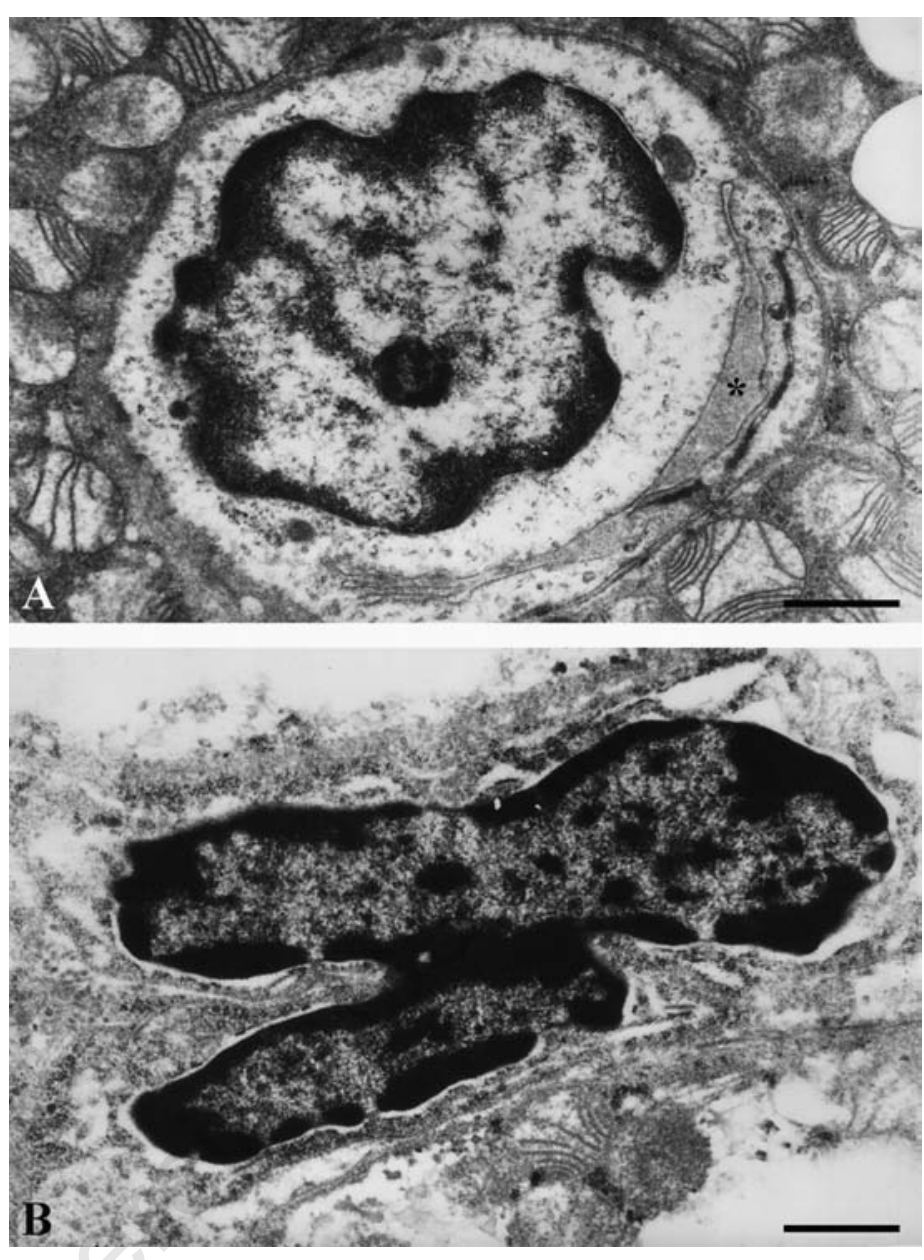

Figure 2. Endothelial cells ultrastructure in brown adipose tissue of hyperinsulinaemic rats: A), acute treatment; endothelial cell with euchromatic, oval nucleus, enclosing capillary lumen (asterisk); B), chronic treatment; apoptotic endothelial cell with heterochromatic, lobulated nucleus and condensed cytoplasm. Scale bars: $1 \mu \mathrm{m}$.

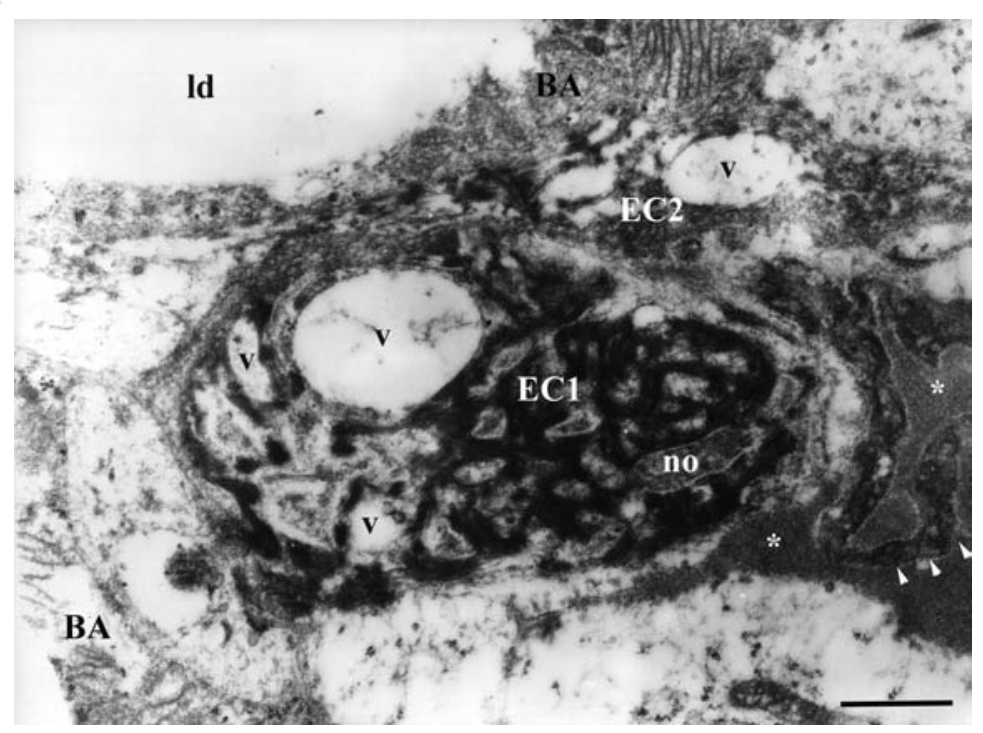

Figure 3. Ultrastructure of apoptotic endothelial cells in brown adipose tissue of hyperinsulinaemic rat (chronic treatment). EC1, endothelial cell with condensed, sparsely distributed chromatic material and with numerous vacuoles (v); EC2, neighboring endothelial cell also shows signs of apoptotic changes and organelle vacuolization, with protrusions (arrowheads) into capillary lumen (asterisks); BA, brown adipocyte; no, nucleolus; ld, lipid droplet. Scale bar: $1 \mu \mathrm{m}$. 
the constant cell ratio maintenance in BAT. ${ }^{8}$ In general, adult tissues do not grow, their mass is stable, and the supporting vasculature is quiescent. ${ }^{30}$ Exceptionally, adipose tissue can grow and regress throughout adulthood. It is highly vascularized and has angiogenic properties. $^{31,32}$ The studies of Rupnick et al. demonstrate that adipose tissue mass can be regulated through the vasculature. ${ }^{9}$ Recent studies indicate that apoptosis is associated with the involution of capillary networks. ${ }^{33-35}$ The circulatory network has the intrinsic capacity to remodel itself to either increase or decrease microcirculation vascularity depending on the metabolic demands of the tissues, which is especially true for the tissue with tremendous plasticity such is BAT. The plasticity of the vascularity is evident during ontogeny and is maintained in both physiologic as well as pathophysiologic circumstances. ${ }^{36-38}$

The physiological meaning of the proapop- totic effect of insulin in BAT after long-term treatment is unknown. Endothelial apoptosis could affect thermogenic function of BAT by decreasing capillary network capacity for substrate intake and heat dispersion. Insulin is thought to be internalized by the vascular ECs via a receptor-mediated process, before it reaches the perivascular space..$^{39}$ This process represents a potential rate-limiting step in peripheral insulin action which can induce delay in insulin-stimulated glucose metabolism at least in some conditions of insulin resistance..$^{40-45}$ Namely, reduced expansion of the capillary network, with attenuation of microcirculatory blood flow to metabolically active tissues, contributes to the impairment of insulin-stimulated glucose and lipid metabolism by altering the transcapillary passage of insulin. ${ }^{46}$ It could be proposed that common cell death of brown adipocytes, as we described earlier, and ECs, as we showed here, induced
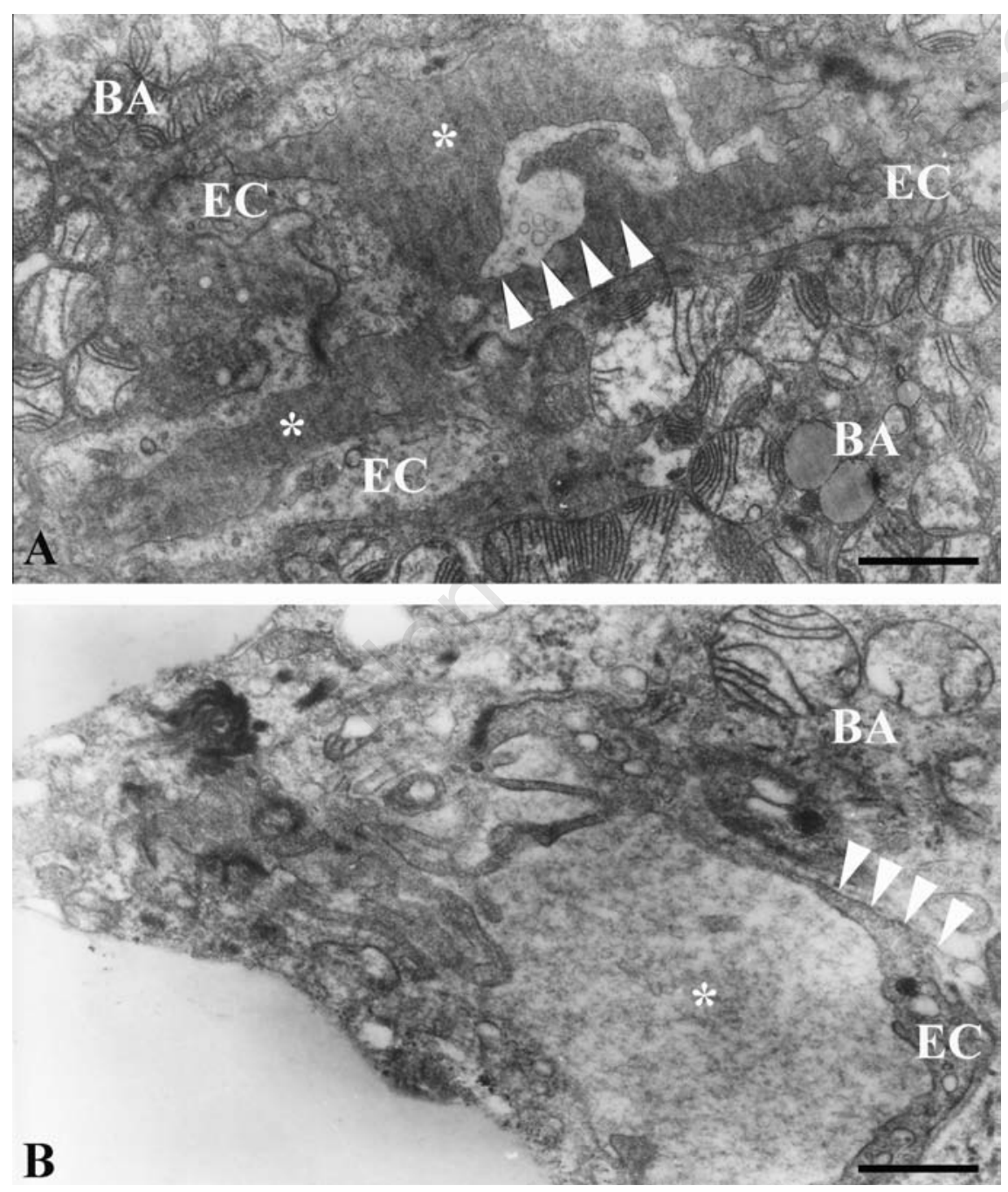

Figure 4. Ultrastructure of the endothelial cell cytoplasmic protrusion (arrowheads) into capillary lumen (asterisks) in brown adipose tissue of hyperinsulinaemic rats: A), chronic treatment; B), acute treatment; BA, brown adipocyte. Scale bars: $1 \mu \mathrm{m}$.

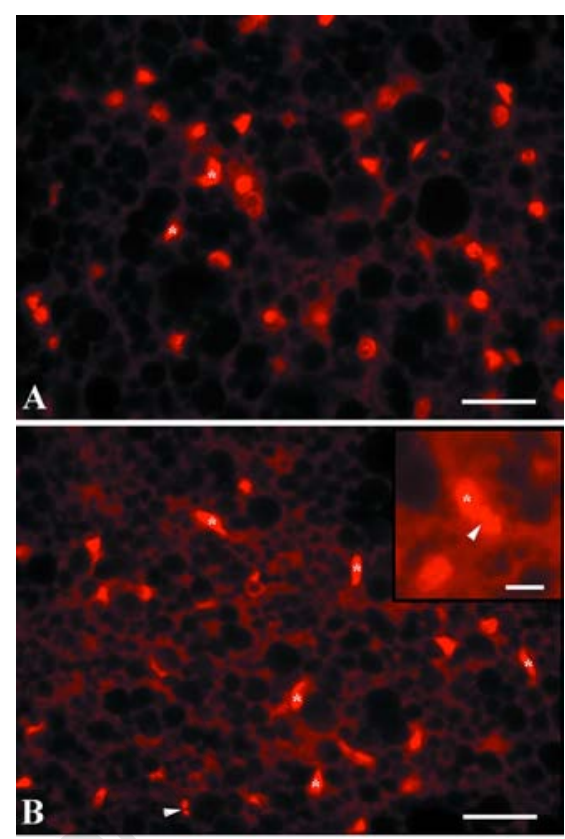

Figure 5. Propidium iodide stained sections of brown adipose tissue of control (A) and insulin-treated rats $(B$, chronic treatment). Condensed nuclei of endothelial cells are denoted by asterisks; insert of B), nuclear fragmentation and micronuclei (arrowheads). Scale bars: $30 \mu \mathrm{m}$.

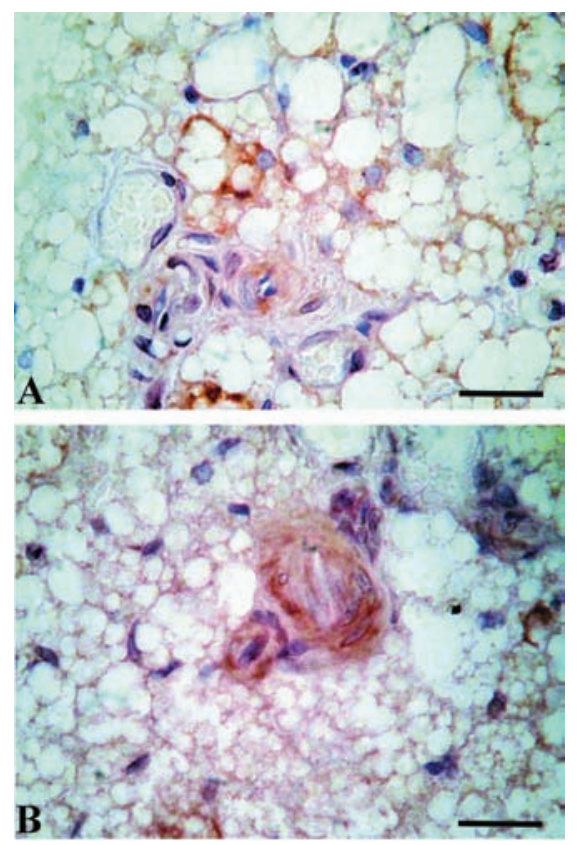

Figure 6. TNF- $\alpha$ immunoexpression in brown adipose tissue of control (A) and hyperinsulinaemic rats $(B$, chronic treatment) reveals higher immunopositivity of small blood vessels endothelial cells in insulin-treated animals. Scale bars: $20 \mu \mathrm{m}$. 
by prolonged exposure to high dose of insulin, might represent an important mechanism involved in the reduction of BAT function in those situations where insulin is continuously present, such as diabetes type 2 or obesity. In agreement with our proposal, it was shown in murine model that partial ablation of BAT leads to obesity, insulin resistance, and decreased oxygen consumption. ${ }^{47,48}$ Also, in humans, the amount of BAT is inversely correlated with body-mass index, especially in older people, suggesting a potential role of BAT in adult human metabolism. ${ }^{49}$ Therefore, although insulin is one of the most relevant positive signals regulating BAT, prolonged presence of high dose of insulin might have a pathological effect that induces apoptotic cell death and contributes to a loss of BAT mass and function, resulting in a secondary insulin resistance.

In addition to its classical metabolic effects to promote fuel storage and stimulate glucose oxidation, insulin has important non-metabolic hemodynamic actions. Namely, insulin promotes capillary recruitment, causes peripheral vasodilatation and increases regional blood flow. ${ }^{50-52}$ These vascular effects of insulin have been interpreted as redistributing flow to a nutritive network, providing increased access for both nutrients and insulin itself to the tissue bed. ${ }^{53}$ Our findings are in disagreement with a large number of in vitro studies in which insulin exerts beneficial effects on endothelium by inhibiting apoptosis. ${ }^{54}$ The study of Chai et al. demonstrated that low concentration of insulin $(30 \mu \mathrm{U} / \mathrm{mL})$ could decrease apoptosis in cultured ECs, while high concentration of insulin $(3 \mathrm{U} / \mathrm{mL})$ induces time- and concentration-dependent apoptosis. $^{55}$ Other studies also demonstrated detrimental effects of insulin on endothelial function which were fully evident only after $4 \mathrm{~h}$ of hyperinsulinemia. ${ }^{56}$ Decreased microvascular density and impaired capillary recruitment are the cardinal findings of microvascular dysfunction affecting capillary perfusion and bloodflow patterns. Microvascular dysfunction is thought to contribute to obesity-associated insulin resistance and hypertension and may thus link central adiposity with cardiovascular risk. $^{57-60}$

Adipokines, such as TNF- $\alpha$, have been implicated in the relationship between microcirculation alterations and metabolic syndrome ${ }^{61}$ It is already shown that insulin resistance is associated with chronic inflammation characterized by abnormal production of proinflammatory cytokines and acute phase reactants ${ }^{62}$ by several cell types, such as adipocytes and macrophages. Also, an increasing body of evidence reveals accumulation of senescent preadipocytes and ECs in the fat tissue of obese and aging subjects, which generate increased amount of cytokines and chemokines which appear to be capable of activating immune responses. ${ }^{63,64}$ Several rodent studies demonstrate that an increase in adipose tissue macrophages worsens insulin sensitivity. ${ }^{65,6} 6$ The most recent study has shown macrophageinduced apoptosis in both preadipocytes and adipocytes mediated in a paracrine manner by cytokine secretion during adipocyte inflammation in vitro ${ }^{67}$ Our ultrastructural analysis of BAT of hyperinsulinaemic rats showed closely positioned macrophages to clusters of apoptotic cells, usually containing few brown adipocytes and ECs (adipo-endothelial clusters). Cinti et al. also described macrophage accumulation in the WAT of obese mice and humans, especially alongside of moribund adipocytes which was coincidental with increased TNF- $\alpha$ gene expression. ${ }^{6}$ TNF- $\alpha$ is a pluripotent, inflammatory cytokine, that appears to elicit a large number of biological effects in different cell systems, including the induction of apoptosis in non-transformed cells. ${ }^{69}$ It is also a principal cytokine involved in EC apoptosis and its concentration increases in pathological conditions, such as diabetes, which initiate or exacerbate vascular endothelial injury. ${ }^{70,71}$ However, the mechanisms of TNF- $\alpha$ proapoptotic effects in the ECs of BAT after hyperinsulinaemia treatment still remain to be elucidated.

Apoptosis of adipose tissue cells is relatively poorly studied phenomenon and the mechanism of apoptosis induced by high dose of insulin in ECs of BAT is also obscure. However, better understanding of the mechanisms that affect adipose tissue mass, including apoptotic cell death, is tremendously important for both obesity-related diseases and conditions resulting in cachexia. Emerging evidence shows that manipulation of adipose tissue neovascularization by angiogenic stimulators and inhibitors affect the expansion and metabolism of fat mass by regulating the growth and remodeling of the adipose tissue vasculature and might therefore offer a novel therapeutic option for the treatment of obesity and related metabolic disorders. ${ }^{72}$ Although it is not proven at this time, the available data point to endothelial apoptosis as the final common pathway through which various insults could contribute to the development of certain diseases. The mechanistic links between structural and functional alterations in BAT microcirculation and metabolic syndrome are complex and remain under discussion. Bearing in mind that hyperinsulinaemia and insulin resistance are among the major causes of metabolic disorders, such as obesity and type 2 diabetes, each of them characterized by endothelial dysfunction, which is a key manifestation in cardiovascular pathologies, ${ }^{73}$ investigation of insulin induced ECs apoptotic changes in such a plastic and metabolically active tissue like BAT is of great significance, and one of our future goals is the elucidation of this process.

\section{References}

1. Kuroshima A. Brown adipose tissue thermogenesis as physiological strategy for adaptation. Jpn J Physiol 1993;43:117-39.

2. Smith RE, Roberts JC. Thermogenesis of brown adipose tissue in cold-acclimated rats. Am J Physiol 1964;206:143-8.

3. Cottle MK, Cottle WH. Adrenergic fibers in brown fat of cold-acclimated rats. J Histochem Cytochem 1970;18:116-9.

4. Foster D0, Frydman ML. Tissue distribution of cold-induced thermogenesis in conscious warm- or cold-acclimated rats reevaluated from changes in tissue blood flow: the dominant role of brown adipose tissue in the replacement of shivering by nonshivering thermogenesis. Can J Physiol Pharmacol 1979;57:257-70.

5. Nnodim J0, Lever JD. The pre- and postnatal development and ageing of interscapular brown adipose tissue in the rat. Anat Embryol (Berl) 1985;173:215-23.

6. Nnodim J0, Lever JD. Neural and vascular provisions of rat interscapular brown adipose tissue. Am J Anat 1988;182:283-93.

7. Rosell S, Belfrage E. Blood circulation in adipose tissue. Physiol Rev 1979;59:1078104.

8. Bukowiecki L, Collet AJ, Follea N, Guay G, Jahjah L. Brown adipose tissue hyperplasia: a fundamental mechanism of adaptation to cold and hyperphagia. Am J Physiol 1982;242:E353-9.

9. Rupnick MA, Panigrahy D, Zhang CY, Dallabrida SM, Lowell BB, Langer R, et al. Adipose tissue mass can be regulated through the vasculature. Proc Natl Acad Sci USA 2002;99:10730-5.

10. Cao Y. Angiogenesis modulates adipogenesis and obesity. J Clin Invest 2007;117: 2362-8.

11. Christiaens V, Lijnen HR. Angiogenesis and development of adipose tissue. Mol Cell Endocrinol 2010;318:2-9.

12. Stefanec T. Endothelial apoptosis: could it have a role in the pathogenesis and treatment of disease? Chest 2000;117:841-54.

13. Nagashima T, Ohinata H, Kuroshima A. Involvement of nitric oxide in noradrenaline-induced increase in blood flow through brown adipose tissue. Life Sci 1994;54:17-25.

14. White MF. Insulin signaling in health and disease. Science 2003;302:1710-1.

15. Liu HY, Cao SY, Hong T, Han J, Liu Z, Cao 
W. Insulin is a stronger inducer of insulin resistance than hyperglycemia in mice with type 1 diabetes mellitus (T1DM). J Biol Chem 2009;284:27090-100.

16. Korac A, Radovanovic J, Davidovic V, Koko V, Nedeljkovic M. Apoptosis in the rat brown adipose tissue after insulin treatment. J Thermal Biology 1999;24:461-4.

17. Porras A, Zuluaga S, Valladares A, Alvarez AM, Herrera B, Fabregat I, et al. Long-term treatment with insulin induces apoptosis in brown adipocytes: role of oxidative stress. Endocrinology 2003;144:5390-401.

18. Hotamisligil GS, Arner P, Caro JF, Atkinson RL, Spiegelman BM. Increased adipose tissue expression of tumor necrosis factoralpha in human obesity and insulin resistance. J Clin Invest 1995;95:2409-15.

19. Uysal KT, Wiesbrock SM, Marino MW, Hotamisligil GS. Protection from obesityinduced insulin resistance in mice lacking TNF-alpha function. Nature 1997;389:610 4.

20. Feinstein R, Kanety H, Papa MZ, Lunenfeld B, Karasik A. Tumor necrosis factor-alpha suppresses insulin-induced tyrosine phosphorylation of insulin receptor and its substrates. J Biol Chem 1993;268:26055-8.

21. Hotamisligil GS, Murray DL, Choy LN, Spiegelman BM. Tumor necrosis factor alpha inhibits signaling from the insulin receptor. Proc Natl Acad Sci USA 1994; 91:4854-8

22. Hotamisligil GS, Peraldi P, Budavari A, Ellis R, White MF, Spiegelman BM. IRS-1mediated inhibition of insulin receptor tyrosine kinase activity in TNF-alpha- and obesity-induced insulin resistance. Science 1996;271:665-8.

23. Hotamisligil GS. Mechanisms of TNFalpha-induced insulin resistance. Exp Clin Endocrinol Diabetes 1999;107:119-25.

24. Nisoli E, Briscini L, Tonello C, De GiuliMorghen C, Carruba MO. Tumor necrosis factor-alpha induces apoptosis in rat brown adipocytes. Cell Death Differ 1997; 4:771-8.

25. Nisoli E, Briscini L, Giordano A, Tonello C, Wiesbrock SM, Uysal KT, et al. Tumor necrosis factor alpha mediates apoptosis of brown adipocytes and defective brown adipocyte function in obesity. Proc Natl Acad Sci USA 2000;97:8033-8.

26. Porras A, Alvarez AM, Valladares A, Benito M. TNF-alpha induces apoptosis in rat fetal brown adipocytes in primary culture. FEBS Lett 1997;416:324-8.

27. Prins JB, Niesler CU, Winterford CM, Bright NA, Siddle K, O'Rahilly S, et al. Tumor necrosis factor-alpha induces apoptosis of human adipose cells. Diabetes 1997;46:1939-44.

28. Tracey KJ, Cerami A. Tumor necrosis fac- tor: a pleiotropic cytokine and therapeutic target. Annu Rev Med 1994;45:491-503.

29. Pankewycz OG, Guan JX, Benedict JF. Cytokines as mediators of autoimmune diabetes and diabetic complications. Endocr Rev 1995;16:164-76.

30. Hobson B, Denekamp J. Endothelial proliferation in tumours and normal tissues: continuous labelling studies. Br J Cancer 1984;49:405-13.

31. Crandall DL, Hausman GJ, Kral JG. A review of the microcirculation of adipose tissue: anatomic, metabolic, and angiogenic perspectives. Microcirculation 1997; 4:211-32.

32. Sierra-Honigmann MR, Nath AK, Murakami C, Garcia-Cardena G, Papapetropoulos A, Sessa WC, et al. Biolo-gical action of leptin as an angiogenic factor. Science 1998;281:1683-6.

33. Lang R, Lustig M, Francois F, Sellinger M, Plesken H. Apoptosis during macrophagedependent ocular tissue remodelling. Development 1994;120:3395-403.

34. Gobe G, Browning J, Howard T, Hogg N, Winterford C, Cross R. Apoptosis occurs in endothelial cells during hypertensioninduced microvascular rarefaction. J Struct Biol 1997;118:63-72.

35. Pollman MJ, Naumovski L, Gibbons GH. Endothelial cell apoptosis in capillary network remodeling. J Cell Physiol 1999;178: 359-70.

36. Risau W. Differentiation of endothelium. FASEB J 1995;9:926-33.

37. Hanahan D, Folkman J. Patterns and emerging mechanisms of the angiogenic switch during tumorigenesis. Cell 1996; 86:353-64.

38. Skalak TC, Price RJ. The role of mechanical stresses in microvascular remodeling. Microcirculation 1996;3:143-65.

39. Cacoub P, Dorent R, Maistre G, Nataf P, Carayon A, Piette C, et al. Endothelin-1 in primary pulmonary hypertension and the Eisenmenger syndrome. Am J Cardiol 1993;71:448-50.

40. Labarrere CA, Nelson DR, Faulk WP. Endothelial activation and development of coronary artery disease in transplanted human hearts. JAMA 1997;278:1169-75.

41. Lopez-Collazo E, Mateo J, Miras-Portugal MT, Bosca L. Requirement of nitric oxide and calcium mobilization for the induction of apoptosis in adrenal vascular endothelial cells. FEBS Lett 1997;413:124-8.

42. Lucas R, Holmgren L, Garcia I, Jimenez B, Mandriota SJ, Borlat F, et al. Multiple forms of angiostatin induce apoptosis in endothelial cells. Blood 1998;92:4730-41.

43. Rounds S, Yee WL, Dawicki DD, Harrington E, Parks N, Cutaia MV. Mechanism of extracellular ATP- and adenosine- induced apoptosis of cultured pulmonary artery endothelial cells. Am J Physiol 1998; 275:L379-88.

44. Walter DH, Haendeler J, Galle J, Zeiher AM, Dimmeler S. Cyclosporin A inhibits apoptosis of human endothelial cells by preventing release of cytochrome $\mathrm{C}$ from mitochondria. Circulation 1998;98:1153-7.

45. Kubota T, Kubota N, Kumagai H, Yamaguchi $\mathrm{S}$, Kozono $\mathrm{H}$, Takahashi $\mathrm{T}$, et al. Impaired insulin signaling in endothelial cells reduces insulin-induced glucose uptake by skeletal muscle. Cell Metab 2011;13:294-307.

46. Cersosimo E, DeFronzo RA. Insulin resistance and endothelial dysfunction: the road map to cardiovascular diseases. Diabetes Metab Res Rev 2006;22:423-36.

47. Lowell BB, V SS, Hamann A, Lawitts JA, Himms-Hagen J, Boyer BB, et al. Development of obesity in transgenic mice after genetic ablation of brown adipose tissue. Nature 1993;366:740-2.

48. Hamann A, Benecke H, Le MarchandBrustel Y, Susulic VS, Lowell BB, Flier JS. Characterization of insulin resistance and NIDDM in transgenic mice with reduced brown fat. Diabetes 1995;44:1266-73.

49. Cypess AM, Lehman S, Williams G, Tal I, Rodman D, Goldfine AB, et al. Identification and importance of brown adipose tissue in adult humans. $\mathrm{N}$ Engl $\mathrm{J}$ Med 2009;360:1509-17.

50. Liang C, Doherty JU, Faillace R, Maekawa $\mathrm{K}$, Arnold S, Gavras H, et al. Insulin infusion in conscious dogs. Effects on systemic and coronary hemodynamics, regional blood flows, and plasma catecholamines. J Clin Invest 1982;69:1321-36.

51. Baron AD. Hemodynamic actions of insulin. Am J Physiol 1994;267:E187-202.

52. Vincent MA, Clerk LH, Lindner JR, Klibanov AL, Clark MG, Rattigan S, et al. Microvascular recruitment is an early insulin effect that regulates skeletal muscle glucose uptake in vivo. Diabetes 2004;53:1418-23.

53. Shankar RR, Wu Y, Shen HQ, Zhu JS, Baron AD. Mice with gene disruption of both endothelial and neuronal nitric oxide synthase exhibit insulin resistance. Diabetes 2000;49:684-7.

54. Hermann C, Assmus B, Urbich C, Zeiher AM, Dimmeler S. Insulin-mediated stimulation of protein kinase Akt: A potent survival signaling cascade for endothelial cells. Arterioscler Thromb Vasc Biol 2000; 20:402-9.

55. Chai W, Chen J, Wang H, Shen J, Ma L, Ma $\mathrm{X}$. The effects of glucose, insulin and oxidized low density lipoprotein on apoptosis in vascular endothelial cells. Chin Med J (Engl) 2000;113:903-6. 
56. Arcaro G, Cretti A, Balzano S, Lechi A, Muggeo M, Bonora E, et al. Insulin causes endothelial dysfunction in humans: sites and mechanisms. Circulation 2002;105: 576-82.

57. Clerk LH, Vincent MA, Jahn LA, Liu Z, Lindner JR, Barrett EJ. Obesity blunts insulin-mediated microvascular recruitment in human forearm muscle. Diabetes 2006;55:1436-42.

58. De Filippis E, Cusi K, Ocampo G, Berria R, Buck S, Consoli A, et al. Exercise-induced improvement in vasodilatory function accompanies increased insulin sensitivity in obesity and type 2 diabetes mellitus. $\mathrm{J}$ Clin Endocrinol Metab 2006;91:4903-10.

59. Jonk AM, Houben AJ, de Jongh RT, Serne EH, Schaper NC, Stehouwer CD. Microvascular dysfunction in obesity: a potential mechanism in the pathogenesis of obesity-associated insulin resistance and hypertension. Physiology 2007;22:252-60.

60. Herrera MD, Mingorance C, RodriguezRodriguez R, Alvarez de Sotomayor M. Endothelial dysfunction and aging: an update. Ageing Res Rev 2010;9:142-52.

61. Wiernsperger N, Nivoit P, De Aguiar LG, Bouskela E. Microcirculation and the metabolic syndrome. Microcirculation 2007;14:403-38.
62. Hotamisligil GS. Inflammatory pathways and insulin action. Int $\mathrm{J}$ Obes Relat Metab Disord 2003;27 Suppl 3:S53-5.

63. Villaret A, Galitzky J, Decaunes P, Esteve D, Marques MA, Sengenes C, et al. Adipose tissue endothelial cells from obese human subjects: differences among depots in angiogenic, metabolic, and inflammatory gene expression and cellular senescence. Diabetes 2010;59:2755-63.

64. Tchkonia T, Morbeck DE, Von Zglinicki T, Van Deursen J, Lustgarten J, Scrable H, et al. Fat tissue, aging, and cellular senescence. Aging Cell 2010;9:667-84.

65. Kamei N, Tobe K, Suzuki R, Ohsugi M, Watanabe T, Kubota N, et al. Over-expression of monocyte chemoattractant protein1 in adipose tissues causes macrophage recruitment and insulin resi-stance. J Biol Chem 2006;281:26602-14.

66. Hirasaka K, Kohno S, Goto J, Furochi H, Mawatari K, Harada N, et al. Deficiency of Cbl-b gene enhances infiltration and activation of macrophages in adipose tissue and causes peripheral insulin resistance in mice. Diabetes 2007;56:2511-22.

67. Keuper M, Bluher M, Schon MR, Moller P, Dzyakanchuk A, Amrein K, et al. An inflammatory micro-environment promotes human adipocyte apoptosis. Mol Cell
Endocrinol 2011; in press.

68. Cinti S, Mitchell G, Barbatelli G, Murano I, Ceresi E, Faloia E, et al. Adipocyte death defines macrophage localization and function in adipose tissue of obese mice and humans. J Lipid Res 2005;46:2347-55.

69. Beutler B, Cerami A. The biology of cachectin/TNF--a primary mediator of the host response. Annu Rev Immunol 1989;7: 625-55.

70. Karsan A. Tumor necrosis factor and endothelial cell death. Trends Cardiovasc Med 1998;8:19-24.

71. Xia Z, Liu M, Wu Y, Sharma V, Luo T, Ouyang $\mathrm{J}$, et al. N-acetylcysteine attenuates TNF-alpha-induced human vascular endothelial cell apoptosis and restores eNOS expression. Eur J Pharmacol 2006; 550:134-42.

72. Cao Y. Adipose tissue angiogenesis as a therapeutic target for obesity and metabolic diseases. Nat Rev Drug Discov 2010;9: 107-15.

73. Kim JA, Montagnani M, Koh KK, Quon MJ. Reciprocal relationships between insulin resistance and endothelial dysfunction: molecular and pathophysiological mechanisms. Circulation 2006;113:1888-904. 